\title{
Just Words
}


This page intentionally left blank 


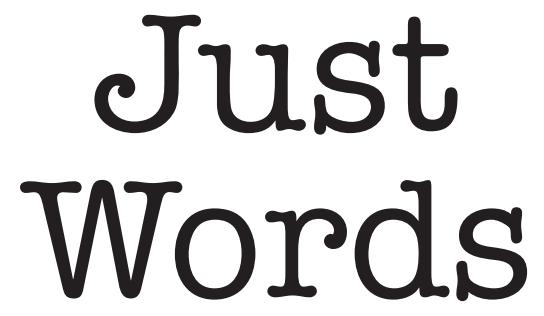

Lillian Hellman, Mary McCarthy, and the Failure of Public Conversation in America

\section{Yale UNIVERSITY PRESS}

New Haven and London 
(C) 2011 by Alan Ackerman.

All rights reserved.

This book may not be reproduced, in whole or in part, including illustrations, in any form (beyond that copying permitted by Sections 107 and 108 of the US Copyright Law and except by reviewers for the public press), without written permission from the publishers.

Yale University Press books may be purchased in quantity for educational, business, or promotional use. For information, please e-mail sales.press@ yale.edu (US office) or sales@yaleup.co.uk (UK office).

Set in Minion type by Westchester Book Group.

Printed in the United States of America.

Illustration credits: xii, Sam Falk/New York Times; xiii, copyright Carlos Freire, photographer, Paris

Library of Congress Cataloging-in-Publication Data

Ackerman, Alan L. (Alan Louis)

Just words : Lillian Hellman, Mary McCarthy, and the failure of public conversation in America / Alan Ackerman.

p. cm.

Includes bibliographical references and index.

ISBN 978-0-300-16712-2 (clothbound : alk. paper) 1. Hellman, Lillian, 1905-1984-Trials, litigation, etc. 2. McCarthy, Mary, 1912-1989-Trials, litigation, etc. 3. Dick Cavett show (Television program) 4. Trials (Libel)-New York (State)—New York-History-2oth century. 5. Television talk shows-Political aspects-United States. 6. Libel and slander-United States-History-2oth century. 7. Freedom of speechUnited States-History-2oth century. 8. Politics and literature-United States-History-2oth century. I. Title.

KF228.H45.A25 2011

$346.73^{\prime} \mathrm{O} 34-\mathrm{dc} 22$

2010052126

A catalogue record for this book is available from the British Library.

This paper meets the requirements of ANSI/NISO Z39.48-1992 (Permanence of Paper).

$\begin{array}{llllllllll}10 & 9 & 8 & 7 & 6 & 5 & 4 & 3 & 2 & 1\end{array}$ 
For Andrea Most 
This page intentionally left blank 